\title{
Jolanta Ignatowicz-Skowrońska, Frazeologizmy jako tworzywo stylu wspótczesnej powieści polskiej, Uniwersytet Szczeciński. Rozprawy i Studia, t. DCCLXX (696), Szczecin 2008, ss. 390
}

Rozprawa habilitacyjna dr Jolanty Ignatowicz-Skowrońskiej składa się z ośmiu rozdziałów i tzw. obudowy, w skład której wchodzą: zwięzły wstęp i równie zwięzłe zakończenie, spis źródeł i wykaz wyzyskanych słowników, obszerna bibliografia, streszczenie w języku angielskim.

Praca ma wiele zalet, a pośród nich godne odnotowania są takie, jak metodologiczna czystość analiz zasobu frazeologicznego, wynotowanego z ponad 200 współczesnych powieści wydanych po 1989 roku, oparcie rozważań na trwałych podstawach teoretycznych (z uwzględnieniem bogatej literatury przedmiotu), łatwość, z jaką autorka wczuwa się w intencje twórców frazeologicznej innowacyjności jako tworzywa stylu, wreszcie - właściwie obrany tok referowania trudnych zagadnień stylistycznych. Także - duży wkład w rozwój polskich badań nad teorią innowacji frazeologicznych, o czym dobitnie świadczy wykrycie i interpretacja innowacji w zakresie aspektu werbalnych składników zwrotów i fraz oraz innowacji w zakresie stopnia przymiotnikowych komponentów wyrażeń. Z dobrze zaplanowanej i po mistrzowsku zrealizowanej rozprawy jasno wynika, że w kręgu polskich frazeologów pojawił się doświadczony badacz, który może w przyszłości znacząco posunąć do przodu stylistyczne badania w zakresie frazeologii.

Autorka rozpoczyna od rozważań nad frazeologizmami jako środkiem stylotwórczym współczesnej prozy, krytycznie omawia dotychczasową klasyfikację innowacji frazeologicznych, kontekstowe przetwarzanie frazeologizmów, modyfikacje ich łączliwości leksykalnej z elementami tła leksykalnego i płaszczyzny gramatycznej frazeologizmu oraz modyfikacje obu tych płaszczyzn objętych jednoczesnym działaniem, czyli sztukę parafrazowania wyrażeń, zwrotów i fraz. Warto tu dodać, że ostatnich z wymienionych prze- 
twarzań nie nazywa aluzjami frazeologicznymi, co jest zrozumiałe, bo dotychczas nie bardzo wiemy, na czym aluzja frazeologiczna się zasadza, a podjęta próba jej opisu w znanej książce Anny Pajdzińskiej Frazeologizmy jako tworzywo wspótczesnej poezji (1993) nie całkiem się powiodła. Najobszerniejsze rozdziały (szósty i siódmy) dotyczą stylistycznej interpretacji innowacyjności frazeologicznej we współczesnych tekstach powieściowych. Tutaj w pełni objawia się zmysł frazeologiczny autorki: wczuwanie się w zamysły twórców powieści, wyznaczanie czterech podstawowych funkcji innowacji (podnoszenie ekspresji, wzmocnienie obrazowości, indywidualizacja językowa postaci, także - funkcja ludyczna, gry językowe itp.). W analizie innowacji posłużono się też (orientacyjnie) metodą ilościowa, wskazując na to, które z nich i w jakim nasileniu występują w tekstach (najczęściej twórcy badanych tekstów sięgają po modyfikacje płaszczyzny leksykalnej frazeologizmów. W sumie mechanizmy przetwarzania zwrotów, wyrażeń i fraz stanowiły kryterium układu treści analitycznej części rozprawy. Ten układ uznaję za w pełni zasadny, świadczący o zmyśle kompozycyjnym autorki.

Osobnego osądu wymagają tzw. innowacje kontekstowe. Żądają bowiem od badacza dużej wprawy, choć dają się analizować powszechnie przyjętymi metodami. Uwagi krytyczne sprowadzić tu można do samego operowania terminem innowacja kontekstowa. Uważam go za niedobry pomysł, który swego czasu podsunął frazeologom prof. Andrzej M. Lewicki, chyba nie do końca uświadamiając sobie fakt, że wszelkie innowacje frazeologiczne ujawniają się w kontekście, a zatem każda innowacja jest innowacją kontekstową. Niestety, termin wszedł do obiegu i trudno go teraz zastapić innym, adekwatnym do opisywanego zjawiska. Nie czynię zarzutu autorce rozprawy, że się nim posługuje, chcąc być w zgodzie z tradycją.

Jeśli chodzi o zmianę znaczeń frazeologizmów, to trzeba zaznaczyć, że dotychczas nie przełamano zmowy milczenia wokół tej problematyki. Trudno te zmiany opisywać, a metoda ich opisu przenoszona z opisu zmian znaczeń wyrazów nie daje pożądanych efektów. Ponadto nie ułatwiają tej działalności słowniki frazeologiczne, które coraz częściej nie respektują filologicznej metody objaśniania znaczeń i dokumentowania ich autentycznymi cytatami z tekstów pisanych. Z obserwacji słownikowych wypływa najczęściej jedno mylne spostrzeżenie, że polskie frazeologizmy mają dane raz na zawsze znaczenia, które „stoją w miejscu”, choć wszyscy zdają sobie sprawę, że język wciąż ewoluuje, rozwija się. Piszę o tym, bo dobrze wiem, że autorka też to widzi, z jej rozważań wynika, by powrócić do tworzenia słowników filologicznych, opartych na materiale wynotowanym z autentycznych tekstów. Podzielam to przekonanie, bo sam od lat apeluję, by opracowywać frazeologiczne słowniki naukowe $\mathrm{z}$ dużą zawartością cytatów dokumentujących semantykę frazeologizmów. 
Kończąc rozważania ogólne nad monografią dr Jolanty Ignatowicz-Skowrońskiej, chciałbym mocno podkreślić, że Frazeologizmy jako tworzywo stylu współczesnej powieści polskiej uzupełniają dotkliwą lukę w polskich badaniach stylistycznych, jaką coraz silniej odczuwano po ukazaniu się doskonale przyjętej książki Anny Pajdzińskiej Frazeologizmy jako tworzywo współczesnej poezji.

Stanisław Baba 